\title{
Inhibition Of Notch Activity Promotes Nonmitotic Regeneration of Hair Cells in the Adult Mouse Utricles
}

\author{
Vincent Lin, ${ }^{1 \star}$ Justin S. Golub, ${ }^{2,3 \star}$ Tot Bui Nguyen, ${ }^{2,3}$ Clifford R. Hume, ${ }^{2,3}$ Elizabeth C. Oesterle, ${ }^{2,3}$ and Jennifer S. Stone ${ }^{2,3}$ \\ ${ }^{1}$ Department of Otolaryngology-Head and Neck Surgery, Sunnybrook Health Sciences Center, University of Toronto, Toronto, Ontario M4N 3M5, Canada, \\ and ${ }^{2}$ Virginia Merrill Bloedel Hearing Research Center and ${ }^{3}$ Department of Otolaryngology-Head and Neck Surgery, University of Washington, Seattle, \\ Washington 98195-7923
}

The capacity of adult mammals to regenerate sensory hair cells is not well defined. To explore early steps in this process, we examined reactivation of a transiently expressed developmental gene, Atoh1, in adult mouse utricles after neomycin-induced hair cell death in culture. Using an adenoviral reporter for Atohl enhancer, we found that Atohl transcription is activated in some hair cell progenitors (supporting cells) $3 \mathrm{~d}$ after neomycin treatment. By $18 \mathrm{~d}$ after neomycin, the number of cells with Atoh 1 transcriptional activity increased significantly, but few cells acquired hair cell features (i.e., accumulated ATOH1 or myosin VIIa protein or developed stereocilia). Treatment with DAPT, an inhibitor of $\gamma$-secretase, reduced notch pathway activity, enhanced Atoh 1 transcriptional activity, and dramatically increased the number of Atoh1-expressing cells with hair cell features, but only in the striolar/juxtastriolar region. Similar effects were seen with TAPI-1, an inhibitor of another enzyme required for notch activity (TACE). Division of supporting cells was rare in any control or DAPT-treated utricles. This study shows that mature mammals have a natural capacity to initiate vestibular hair cell regeneration and suggests that regional notch activity is a significant inhibitor of direct transdifferentiation of supporting cells into hair cells following damage.

\section{Introduction}

Hair cells in the vestibular portion of the inner ear are essential for body orientation and balance. They are vulnerable to ototoxic drugs, infection, and disease, and their loss causes balance impairments. In mammals, hair cells are produced during a finite developmental period (Ruben, 1967). Mature mammals seem to be able to replace hair cells in utricles (otolithic vestibular organs) in some conditions (Forge et al., 1993, 1998; Warchol et al., 1993; Kuntz and Oesterle, 1998; Kawamoto et al., 2009) but not in others (Rubel et al., 1995). It is unclear whether hair cells are restored by cellular regeneration or repair, since most damage

\footnotetext{
Received April 25, 2011; revised July 25, 2011; accepted Sept. 2, 2011.

Author contributions: J.S.G., E.C.O., and J.S.S. designed research; V.L., J.S.G., T.B.N., C.H., E.C.O., and J.S.S. performed research; C.H. contributed unpublished reagents/analytic tools; V.L., J.S.G., T.B.N., and J.S.S. analyzed data; J.S.S. wrote the paper.

This work was supported by the Hearing Regeneration Initiative (an anonymous privately supported consortium at the Virginia Merrill Bloedel Hearing Research (enter) and NIH Grants DC03696 (R01, J.S.S.), DC003944 (R01, E.C.O.), DC006437 (K08, C.R.H.), DC00018 (T32, Otolaryngology), DC04661 (P30, Rubel), and HD02274 (P30, Guralnick). We thank Jane Johnson (University of Texas Southwestern Medical School) for donating polyclonal antiMATH1 antibody and the J2XnGFP construct. We appreciate Lisa Cunningham (Medical University of South Carolina) for sharing myosin VIla labeling protocols and Stefan Heller (Stanford University) for donating guinea pig antimyosin VIla antibodies. We appreciate constructive comments on the manuscript by David Raible and Edwin Rubel. We thank Edwin Rubel for sharing facilities, Robin Gibson for assistance with PCR, Debbie Bratt and Ming Xiao for assistance with virus generation, Jia Lin Shang for help with immunolabeling, Glen MacDonald for assistance with microscopy, and Kevin Whitham and Brandon Warren for assistance with computer technology.

*V.L. and J.S.G. contributed equally to this work.

The authors declare no competing financial interests.

Correspondence should be addressed to Jennifer S. Stone, CHDD CD176 Box 357923, Virginia Merrill Bloedel Hearing Research Center, Department of Otolaryngology-Head and Neck Surgery, University of Washington, Seattle, WA 98195-7923. E-mail: stoner@u.washington.edu.

DOI:10.1523/JNEUROSCI.2057-11.2011

Copyright $\odot 2011$ the authors $\quad 0270-6474 / 11 / 3115329-11 \$ 15.00 / 0$
}

methods do not kill all original hair cells and only rare replacement hair cells appear to be formed by cell division.

The basic helix-loop-helix (bHLH) transcription factor, atonal homolog 1 or ATOH1, is transiently expressed in embryonic hair cells and is required for their differentiation (Bermingham et al., 1999; Shailam et al., 1999; Chen et al., 2002; Woods et al., 2004). In chickens and zebrafish, which spontaneously regenerate hair cells (for review, see Brignull et al., 2009), Atoh1 is reactivated in hair cell progenitors (supporting cells) and temporally accumulates in young regenerated hair cells (Cafaro et al., 2007; Ma et al., 2008). In adult mouse utricles, ATOH1immunoreactive cells appear shortly after injury (Wang et al., 2010). Forced overexpression of Atoh 1 in mammalian supporting cells (Zheng and Gao, 2000; Kawamoto et al., 2003; Shou et al., 2003; Woods et al., 2004; Staecker et al., 2007; Gubbels et al., 2008) or other nonsensory cells (Huang et al., 2009) promotes their direct conversion into hair cells without cell division. Therefore, it remains unclear why spontaneous Atohl reactivation after damage does not trigger more reliable and substantial hair cell replacement in mammals.

In the developing inner ear, Atoh1 transcription is repressed by activation of the receptor, notch (Lanford et al., 2000; Zheng and Gao, 2000; for review, see Lewis, 1998; Kageyama et al., 2005). Ligand-binding triggers extracellular cleavage of notch by tumor necrosis factor $\alpha$ converting enzyme (TACE) and intracellular cleavage by $\gamma$-secretase (Kopan and Ilagan, 2009). The notch intracellular domain enters the nucleus and interacts with CSL (CBF-1/SuH/Lag-1) transcription factors. This interaction drives the transcription of genes encoding the bHLH transcriptional repressors, HES/HER/E(SPL), whose targets include Atoh1. Dur- 
ing inner ear development, notch activity promotes sensory specification and then limits organ size and hair cell numbers via lateral inhibition (for review, see Kelley, 2006). In nonmammalian vertebrates, notch signaling antagonizes hair cell regeneration (Ma et al., 2008; Daudet et al., 2009; Slattery and Warchol, 2010). However, in mature mammals, notch inactivation does not promote hair cell regeneration in the organ of Corti (Hori et al., 2007), and a role for notch in modulating vestibular hair cell regeneration is unexplored.

Using organotypic cultures of adult mouse utricles, we show that supporting cells upregulate Atohl transcriptional activity shortly after hair cell damage, but only rare cells acquire advanced hair cell features. Blocking notch activity with inhibitors of $\gamma$-secretase or TACE accelerates regional hair cell regeneration by promoting supporting cells to convert into new hair cells without dividing.

\section{Materials and Methods}

Animals. Six- to 9-week-old (adult) Swiss Webster mice were obtained from Charles River Laboratories or Harlan Laboratories and maintained by the Department of Comparative Medicine, with ad libitum access to food and water. Male and female mice were used for experiments. Mice were killed via cervical dislocation followed by decapitation. All experiments and specific procedures were approved by the University of Washington Institutional Animal Care and Use and Biosafety Committees and adhered to NIH-approved standards.

Organotypic cultures. Whole utricles were dissected from 6- to 9 weekold mice and cultured free-floating, as described previously (Yamashita and Oesterle, 1995; Cunningham et al., 2002). Otoconia were removed using a gentle stream of PBS ejected from a $25 \mathrm{G}$ needle and syringe. Utricles were cultured in $500 \mu \mathrm{l}$ of media in untreated 24-well flatbottom plates or $100 \mu \mathrm{l}$ of media in untreated 96-well flat-bottom plates (BD Falcon). All cultures were maintained at $37^{\circ} \mathrm{C}$ in $5 \% \mathrm{CO}_{2} / 95 \%$ air. Half volumes of media were supplemented with fresh media daily.

Culture media consisted of DMEM (Invitrogen), 1\% fetal bovine serum (Atlanta Biologicals), and 0.5\% dimethyl sulfoxide (DMSO; SigmaAldrich) as a negative control for experiments in which DAPT and TAPI- 1 were included in media (see below). Neomycin sulfate stock (10 $\mathrm{mg} / \mathrm{ml}$ in $0.9 \% \mathrm{NaCl}$, from Sigma-Aldrich) was diluted in culture media to $4 \mathrm{~mm}$. $\gamma$-Secretase inhibitor IX, also called DAPT $(N-[N-(3,5-$ difluorophenacetyl)-1-alanyl]-S-phenylglycine $t$-butyl ester; catalog number 565784), was purchased from EMD Chemicals, diluted with $100 \%$ DMSO to a stock concentration of $10 \mathrm{~mm}$, and used at working concentrations of 10 or $50 \mu \mathrm{M}$. The TACE inhibitor TAPI-1 (catalog number 579051, EMD Chemicals) was diluted with 100\% DMSO to a stock concentration of $10 \mathrm{~mm}$. Stock solution was diluted in culture media to a working concentration of $50 \mu \mathrm{M}$. In experiments using DAPT or TAPI- 1 , matching concentrations of DMSO $(0.1 \%$ or $0.5 \%)$ were used as vehicle controls, and control and experimental groups were cultured simultaneously. Bromodeoxyuridine (BrdU, Sigma-Aldrich) was included at $1 \mu \mathrm{M}$.

Adenovirus transduction. Adenovirus serotype 5 driving green fluorescence protein (GFP) under control of the cytomegalovirus (CMV) promoter (Ad5-CMV-GFP) was obtained from Vector BioLabs. The optimal viral concentration, which caused moderate transduction and minimal cellular damage relative to other concentrations, was selected after culturing utricles as follows with varying dilutions of the virus $\left(10^{7}-10^{9}\right.$ transduction units). One or two freshly explanted utricles were placed in a well from a 96-well plate containing $30-50 \mu \mathrm{l}$ of viral solution and incubated overnight at $37^{\circ} \mathrm{C}$ on a slow rotator. After rinsing and culturing for 1 additional day in virus-free media, utricles were fixed with phosphate-buffered 4\% paraformaldehyde (Sigma-Aldrich) for $30 \mathrm{~min}$. We used confocal microscopy to compare the following features across the cultures: (1) relative efficiency of transduction in the utricular sensory epithelium (SE); (2) hair cell morphology, as assessed using myosin VIIa labeling; and (3) health of hair cell and supporting cell nuclei, as assessed using DAPI (4', $6^{\prime}$-diamidino-2-phenylindole) labeling (see be- low for details). The concentration we found to be optimal- $1.2 \times 10^{8}$ transduction units per milliliter of media (2 parts Basal Medium Eagle media and 1 part Earle's balanced salt solution)—was used for all experiments reported here.

Ad5-Atoh1-GFP was engineered to drive GFP transcription under control of the mouse Atoh1 3' enhancer. A 1391 nt Xho1-Sall DNA fragment of J2XnGFP (Jane Johnson, University of Texas Southwestern Medical School, Dallas, TX) (Helms et al., 2000) containing two copies of the Atoh1 enhancer, GFP, $\beta$-globin promoter, a nuclear localization signal sequence, and the bovine-growth hormone polyadenylation signal, was cloned into the Xho1 site of pShuttle plasmid (Stratagene/Agilent Technologies) (Timmer et al., 2001). This construct, pShuttle-Atoh1GFP, was recombined with pAdE-(delta)pol using a modified AdEasy system (Luo et al., 2007) using C7 \&HEK 293 (Amalfitano and Chamberlain, 1997; Wise et al., 2010) to generate replication-incompetent serotype 5 adenovirus (Ad5-Atoh1-GFP). Virus was amplified through several rounds and purified using ion exchange chromatography membranes (Vivascience, Sartorius). Viral concentrations were estimated by spectrophotometry $\left(\mathrm{OD}_{260}\right)$ and transduction of cultured cell lines (HT 1080 ) to verify GFP expression. Biological titers were $10-50 \%$ of spectrophotometric titers. The optimal dose for Ad5-Atoh1-GFP was $4 \times 10^{8}$ optical particle units in $30-50 \mu \mathrm{l}$ of media. Transduction parameters were identical to those used with Ad5-CMV-GFP (except for dose).

Viral stocks were stored at $-80^{\circ} \mathrm{C}$. For all experiments, viral treatment was performed overnight on freshly explanted utricles, before neomycin treatment, and cultures were generously rinsed with media after viral treatment.

Analysis of notch target gene expression. Quantitative real-time PCR (qRTPCR) was used to examine expression of notch pathway genes. Three conditions were examined: (1) adult mouse utricles cultured with 0.5\% DMSO for $4 \mathrm{~d}$, including an initial $1 \mathrm{~d}$ neomycin treatment; (2) adult mouse utricles cultured with $50 \mu \mathrm{M}$ DAPT for $4 \mathrm{~d}$, including an initial $1 \mathrm{~d}$ neomycin treatment; and (3) postnatal day 1 mouse brain. For conditions 1 and 2, a total of five PCR runs were performed (10-18 utricles per run). For condition 3, portions from one telencephalon were used for one PCR run.

Whole utricles were harvested, placed in RNeasy R1 Buffer (Qiagen), triturated, and stored at $-80^{\circ} \mathrm{C}$. The RNeasy Micro kit (Qiagen) was used to isolate RNA, and first-strand cDNA was generated using PowerScript Reverse Transcriptase (Clontech), diluted 1:20 in $10 \mathrm{~mm}$ Tris- $\mathrm{HCl} / 0.1$ mM EDTA, pH 8.0. Approximately 60 ng of cDNA for each condition were processed using an iCycler (Bio-Rad). Primers for $\beta$-actin, Notch1-4, Jag2, Dll1, Hes1, Hes5, Hey1, and Hey3 were ordered from Eurofin MWG Operon; sequences are available upon request. Two duplicate wells were processed per primer set for each run. Threshold cycle (Ct) was set at 100 relative fluorescent units. Relative gene expression levels are described as $2^{-\mathrm{dCt}}$, where $\mathrm{dCt}$ equals the difference in $\mathrm{Ct}$ between the target gene and $\beta$-actin. To estimate fold differences in transcript levels between conditions 1 and 2 , the $2^{-\mathrm{ddCt}}$ method was used (Pfaffl, 2001).

Histological labeling. All procedures were conducted at room temperature, unless otherwise stated. Whole-mount utricles were fixed for $1 \mathrm{~h}$ with phosphate-buffered $4 \%$ paraformaldehyde. Utricles were permeabilized with $0.05-0.2 \%$ Triton X-100 (Sigma-Aldrich) in PBS for $1-2 \mathrm{~h}$. Utricles undergoing BrdU immunolabeling were incubated in $2 \mathrm{~N} \mathrm{HCl}$ for $30 \mathrm{~min}$ to denature DNA. All utricles were incubated in blocking solution [10\% normal horse serum or normal goat serum (Vector Laboratories) in $0.05 \%$ Triton X-100] for 30 min before primary antibody incubation. All antibodies were diluted in this blocking solution.

Certain utricles were incubated with rabbit anti-ATOH1 antibodies (1:300) (from Jane Johnson, University of Texas Southwestern Medical Center; Helms and Johnson, 1998; Helms et al., 2000; Chen et al., 2002; Cafaro et al., 2007) for two nights at $4^{\circ} \mathrm{C}$ followed by $4 \mathrm{~h}$ at room temperature. After rinsing with PBS, utricles were incubated in goat antirabbit horseradish peroxidase-conjugated secondary antibodies (1:400, Invitrogen) overnight at $4^{\circ} \mathrm{C}$ followed by $4 \mathrm{~h}$ at room temperature. The Tyramide Signal Amplification Alexa 488 kit (Invitrogen) was applied according to the manufacturer's instructions. Hair cells were labeled by applying guinea pig anti-myosin VIIa antibodies (from Stefan Heller, 
Table 1. Numerical data from Ad5-Atoh1-GFP experiments

\begin{tabular}{|c|c|c|c|}
\hline Treatment & $\begin{array}{l}\text { Mean number of } \\
\text { GFP + cells } \\
\text { per SE ( } \pm \text { SD) }\end{array}$ & $\begin{array}{l}\text { Number of } \\
\text { GFP }+/ M y 0+ \\
\text { cells per } S E( \pm S D)\end{array}$ & $\begin{array}{l}\% \text { GFP + cells } \\
\text { that were Myo + }\end{array}$ \\
\hline Control (not cultured) & 0 & 0 & $\mathrm{~N} / \mathrm{A}$ \\
\hline \multicolumn{4}{|l|}{ DMSO } \\
\hline $4 \mathrm{~d}, \mathrm{noNeo}(n=4)$ & $24.8( \pm 22.4)$ & $0.5( \pm 0.6)$ & 2.0 \\
\hline 3 d post-Neo $(n=9)$ & $31.0( \pm 22.9)$ & $1.7( \pm 1.9)$ & 5.5 \\
\hline 6 d post-Neo $(n=9)$ & $67.7( \pm 49.4)$ & $0.2( \pm 0.4)$ & 0.3 \\
\hline 10 d post-Neo $(n=4)$ & $125.3( \pm 57.1)$ & $1.3( \pm 1.3)$ & 1.0 \\
\hline $18 \mathrm{~d}$ post-Neo $(n=6)$ & $183.0( \pm 92.8)$ & $6.2( \pm 3.6)$ & 3.4 \\
\hline \multicolumn{4}{|l|}{ DAPT } \\
\hline $4 \mathrm{~d}, \mathrm{noNeo}(n=4)$ & $34.8( \pm 12.6)$ & $7.5( \pm 3.0)$ & 21.6 \\
\hline 3 d post-Neo $(n=7)$ & $28.1( \pm 40.7)$ & $2.3( \pm 1.8)$ & 8.2 \\
\hline 6 d post-Neo $(n=9)$ & $148.3( \pm 141.4)$ & $4.1( \pm 5.1)$ & 2.8 \\
\hline $10 \mathrm{~d}$ post-Neo $(n=10)$ & $137.9( \pm 81.9)$ & $17.1( \pm 23.7)$ & 12.4 \\
\hline 18 d post-Neo $(n=7)$ & $375.9( \pm 171.2)$ & $181.7( \pm 129.3)$ & 48.3 \\
\hline
\end{tabular}

$n$, Number of utricles.

Stanford University) overnight at $4^{\circ} \mathrm{C}$ followed by incubation with goat anti-guinea pig IgG conjugated to Alexa594 (Invitrogen) for $2 \mathrm{~h}$. For BrdU labeling, utricles were incubated in mouse anti-BrdU antibody (1:300, Becton Dickinson) followed by donkey anti-mouse IgG conjugated to Alexa594. Following immunolabeling, utricles were wholemounted in Vectashield (Vector Laboratories) or Fluoromount (Southern Biotech).

Additional hair cell labeling was performed by blocking utricles with $2 \%$ bovine serum albumin, $0.8 \%$ normal goat serum, and $0.4 \%$ Triton $\mathrm{X}-100$ for $4 \mathrm{~h}$. Rabbit anti-myosin VIIa antibodies (Proteus Biosciences) were applied overnight at $4^{\circ} \mathrm{C}$ followed by incubation with goat antirabbit IgG conjugated to Alexa594 (Invitrogen) for $4 \mathrm{~h}$. This method resulted in equivalent labeling compared to guinea pig anti-myosin VIIa antibodies described above. Additional primary antibodies were used: anti-calbindin (AB1778, Millipore Bioscience Research Reagents), anticalmodulin (C3545, Sigma-Aldrich), rabbit anti-GFP (Invitrogen), and anti-Jag1, Santa Cruz Biotechnology).

All secondary antibodies were purchased from Invitrogen. Some utricles were counterstained with nuclear dye (DAPI, $1 \mu \mathrm{g} / \mathrm{ml}$ for $10 \mathrm{~min}$, Sigma-Aldrich) to help with orientation during confocal imaging. Additional utricles were counterstained with phalloidin (Invitrogen) at 10 $\mu \mathrm{g} / \mathrm{ml}$ to label filamentous actin, which binds filamentous actin, an abundant protein in mature and immature stereocilia.

Microscopy and quantitative analysis. Fluorescent imaging was performed using an Olympus FV-1000 confocal microscope. We generated single $z$-series stacks of images for each entire utricle that extended from the lumenal surface past the basement membrane and into the stroma. All cell counts were performed off-line with ImageJ.

In utricles that were cultured, images of the entire utricular SE were generated using a $20 \times$ objective. We counted every cell in the SE that had the following labeling pattern: myosin VIIa-positive (+), ATOH1+/myosin VIIa + , GFP+, GFP+/myosin VIIa+ (Figs. 1, 3, 4, Table 1), or BrdU + . Only utricles with fully intact SE were analyzed. To avoid counting fragments of injured hair cells, only cells that possessed detectable, healthy-appearing nuclei were included in counts.

To estimate numbers of myosin VIIa + cells (hair cells) in control, noncultured utricles (Fig. 1), images of the entire utricular SE were generated using a $20 \times$ objective. We randomly sampled fifteen $1980 \mu \mathrm{m}^{2}$ regions in the SE from each of these images as follows. A $12 \times 12$ grid was overlaid on the utricle image, and a random number generator was used to create a list of $X / Y$ coordinates, ranging from 1 to 12 . Corresponding regions on the grid that fell wholly within the SE were included. The process continued until 15 regions were counted, which constituted $21 \%$ of the SE. Counts were summed across areas and averaged across utricles. Averages were multiplied by a factor of $4.76(100 \% / 21 \%)$ to obtain the estimated number of hair cells per utricle.

Adenoviral transduction efficiencies were measured by counting GFP + cells in images of 14 randomly selected $11,125 \mu \mathrm{m}^{2}$ regions (at $60 \times$ ) from six utricles that were cultured for $1-2 \mathrm{~d}$ after transduction.
All qualitative conclusions are based on 4-12 utricles studied in each experimental manipulation discussed. For all quantitative comparisons of histological preparations, the numbers of utricles assessed are provided in the Results section, Table 1, or the figure legends. All statistical analyses were performed using ANOVA, with Fisher PLSD (protected least significant difference) post hoc tests for effects of treatment or time in culture (Statview 4.5, Abacus Concepts). Oneway analyses were also performed to assess effects of time on each measurement within a treatment group. Effects were considered statistically significant if $p \leq 0.05$.

\section{Results}

One-day neomycin treatments cause extensive, but incomplete, hair cell loss in adult utricles

The goal of this study was to determine the degree to which new hair cells are formed in drug-damaged adult mouse utricles and to test whether manipulation of notch signaling can enhance this process. Aminoglycoside antibiotics are ototoxins that kill hair cells. Complete hair cell loss in adult mouse vestibular epithelia is difficult to achieve, since aminoglycosides cause systemic toxicity that reaches lethal levels before maximum damage occurs (e.g., Oesterle et al., 2008; Taylor et al., 2008). Larger lesions require surgical drug delivery (e.g., Kawamoto et al., 2009). Therefore, we induced hair cell loss in organotypic cultures using the aminoglycoside antibiotic neomycin (Yamashita and Oesterle, 1995; Cunningham et al., 2002). Hair cells were examined in control utricles (explanted and fixed immediately) and in utricles at different times after neomycin treatment using immunolabeling for markers specific to hair cells in mice, myosin VIIa or calmodulin (Hasson et al., 1997; Cunningham et al., 2002).

Control utricles that were explanted and fixed without culturing (Fig. $1 A, I$ ) had an average of $3472( \pm 231$ SD) myosin VIIa+ cells. These numbers were similar to hair cell numbers reported for adult mice in previous studies (e.g., Kirkegaard and Nyengaard, 2005). Utricles cultured for $1 \mathrm{~d}$ without neomycin (Fig. $1 B, I$ ) showed considerable hair cell loss; counts of myosin VIIa+ hair cells were $44 \%$ of controls. Utricles cultured for $4 \mathrm{~d}$ without neomycin exhibited further loss, to $34 \%$ of controls, but this difference was not statistically significant $(p=0.745)$ (Fig. $1 I)$. This spontaneous hair cell loss was likely due to damage from culture conditions. Treatment with high-dose, $4 \mathrm{~mm}$ neomycin for $1 \mathrm{~d}$ accelerated hair cell loss (Fig. 1C,D,I) such that numbers reached $12 \%$ of controls by $4 \mathrm{~d}$ in vitro. Qualitatively similar results were seen in cultures that were labeled with antibodies to calmodulin (Fig. 1E-H).

To examine spatial patterns of hair cell loss, utricles were immunolabeled for calbindin, whose expression is limited to hair cells and afferent nerve calyces in the striola in mice (Cunningham et al., 2002). The striola is a "reverse C-shaped" region of the SE, within which hair cell stereociliary bundles undergo a $180^{\circ}$ shift in planar polarity and additional specializations exist (e.g., Desai et al., 2005; Li et al., 2008). The specificity of anti-calbindin antibodies for the striola was lost by $4 \mathrm{~d}$ in neomycin-treated utricles (Fig. $1 E-H$ ). Calbindin became detectable in surviving hair cells throughout the utricle, making it impossible to discern the position of the striola in older cultures. Nonetheless, it was clear that extensive hair cell loss occurred throughout the utricle, in both striolar and extrastriolar regions.

\section{New hair cell differentiation is initiated in adult mouse utricles after damage}

We examined whether new hair cell production is triggered in adult mouse utricles after neomycin treatment in vitro. Since 
Atoh1 transcription is negligible in the mature utricular SE (Shailam et al., 1999) but is required during hair cell development (Bermingham et al., 1999), we reasoned that the reactivation of Atoh1 in supporting cells after damage might reflect their initial transdifferentiation into hair cells.

The Atoh1-GFP transgenic mouse encodes GFP under control of the 3' Atoh1 enhancer in a manner that reports Atoh1 transcription (Lumpkin et al., 2003). This mouse has been valuable in dissecting early steps in normal hair cell development (Chen et al., 2002), but it was not useful for our studies because GFP fluorescence is retained in the adult utricular SE despite low Atoh1 expression levels. To detect the upregulation of Atoh1 transcription, we generated a serotype 5 adenovirus (Ad5) encoding GFP in the same configuration as the Atoh1-GFP reporter mouse, which we named Ad5-Atoh1GFP. This vector preferentially infects supporting cells in cultured adult mouse utricles (see below), allowing us to specifically examine Atoh1 reactivation in supporting cells.

First, we tested the efficiency and specificity of Ad5 transduction using a version of the virus that drives GFP expression via the CMV promoter (Ad5-CMV-GFP). Utricles were explanted, treated overnight with virus (in neomycin-free media), rinsed, and maintained in neomycin-free media for 1 or 2 more days. Media included $0.5 \%$ DMSO, a solvent used in later experiments. Utricles were labeled to detect myosin VIIa and the nuclear marker, DAPI. Strong GFP fluorescence was seen throughout the SE (Fig. $2 A, A^{\prime}$ ). The distribution of GFP in utricles was variable, but in a given utricle, cells in striolar and extrastriolar regions were consistently GFP +. Quantitative analysis showed that, on average, $27 \%$ ( $\pm 13 \%)$ of SE cells were GFP +. All GFP + cells were myosin VIIa- (negative), stretched from the basal lamina to the lumen, and had nuclei located in the basal compartment of the SE, correlating with the supporting cell layer (Fig. $2 B-C^{\prime}$ ). These observations demonstrate that Ad5 preferentially transduces supporting cells in adult mouse utricles. This finding is consistent with another study in postnatal rat (Huang et al., 2009). However, it differs from adenoviral transduction specificity in cultured embryonic and neonatal mouse utricles, where the virus transduces primarily hair cells (e.g., Holt et al., 1999; J. S. Stone, unpublished observations).

Next, we examined GFP in utricles transduced with Ad5Atoh1-GFP. Utricles were explanted and cultured overnight with virus. After rinsing, cultures were treated for $1 \mathrm{~d}$ with neomycin, rinsed, and maintained for different periods in media lacking
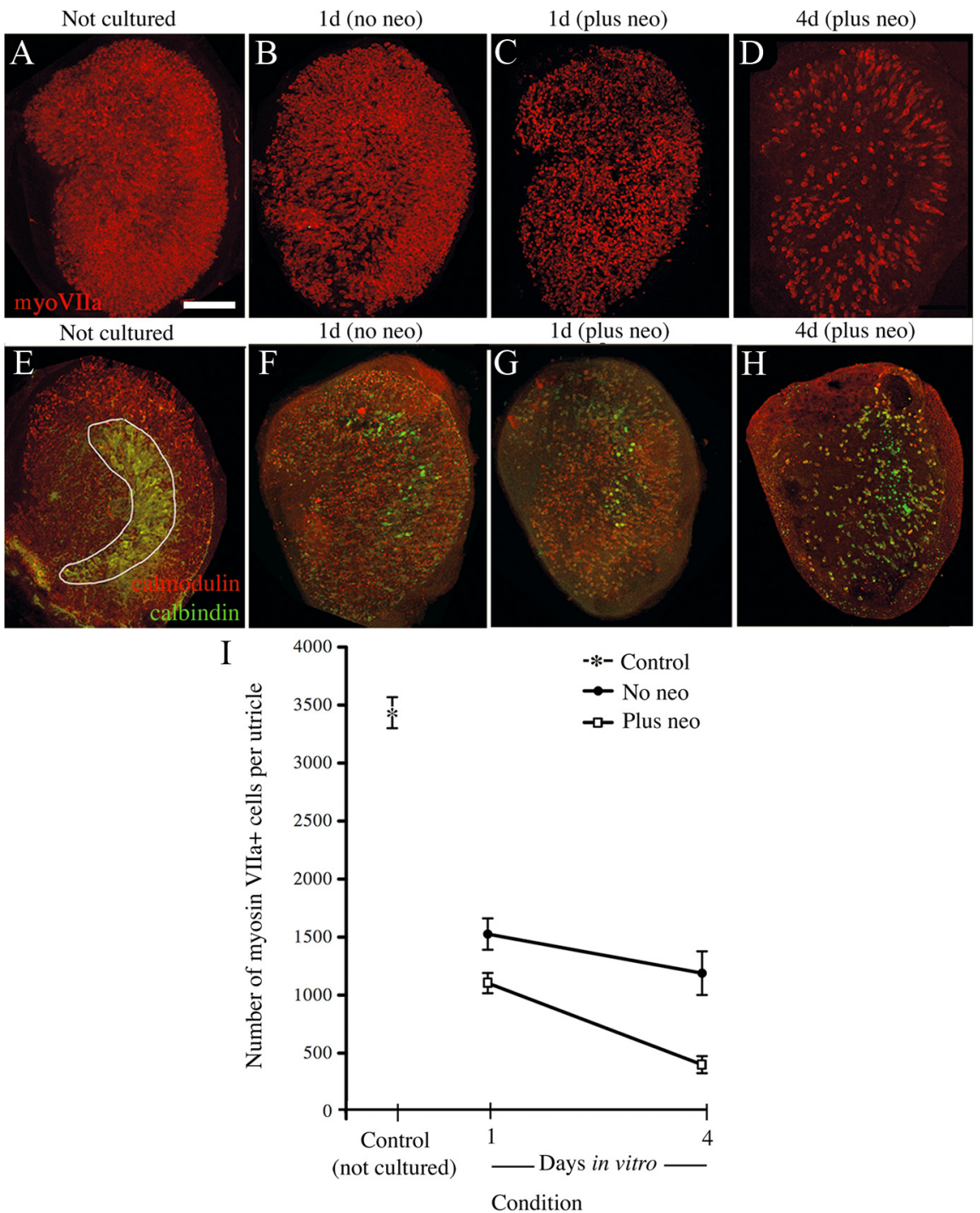

Figure 1. In vitro neomycin treatment causes significant, but not complete, hair cell loss in the adult mouse utricle. Images are brightest-point projections of confocal z-series through the entire SE from utricles that were dissected and fixed immediately (not cultured) $(\boldsymbol{A}, \boldsymbol{E})$ or dissected and cultured for $1 \mathrm{~d}$ with 4 mм neomycin followed by various periods without neomycin $(\boldsymbol{B}-\boldsymbol{D}, \boldsymbol{F}-\boldsymbol{H})$, before fixation. Times represent total time in culture. Utricles were immunolabeled to detect myosin VIla $(\boldsymbol{A}-\boldsymbol{D})$ or calmodulin (red) and calbindin (green) $(\boldsymbol{E}-\boldsymbol{H})$. All utricles are oriented in the same manner, with the presumed striolar region in the same general position as indicated in $\boldsymbol{E}$. Anatomical landmarks, including the peripheral shape of the utricle, were used to aid in orientation. Progressive hair cell loss was observed in myosin Vlla-labeled (red) tissue $(\boldsymbol{B}-\boldsymbol{D})$ and calmodulin (red)/calbindin (green) labeled tissue $(\boldsymbol{F}-\boldsymbol{H})$ compared to respective controls $(\boldsymbol{A}, \boldsymbol{E})$, although some residual hair cells were evident at $4 \mathrm{~d}$ in vitro $(\boldsymbol{D}, \boldsymbol{H})$. Note the loss of striola-specific calbindin labeling (green backwards " $\boldsymbol{C}$ " shape, in $\boldsymbol{E}$ ) over time $(\boldsymbol{F}-\boldsymbol{H})$. $\boldsymbol{I}$, Numbers of myosin VIla + cells are utricles for $1 \mathrm{~d} /$ No neo; $n=4$ utricles for $4 \mathrm{~d} /$ No neo), and utricles with neomycin treatment (Plus neo, white squares; $n=4$ utricles for $1 \mathrm{~d} /$ Plus neo; $n=9$ utricles for $4 \mathrm{~d} /$ Plus neo). Error bars represent SEMs. All data points are significantly different from one another $(p<0.05$ ) except for two comparisons: $1 \mathrm{~d} /$ No neo versus $4 \mathrm{~d} /$ No neo and $1 \mathrm{~d} /$ /Plus neo versus $4 \mathrm{~d} /$ /No neo. Neo, Neomycin; MyoVIla, myosin Vlla. Scale bar, $100 \mu \mathrm{m}$.

neomycin but containing DMSO. For all experiments, utricles were labeled with antibodies to GFP to enhance visualization. At $3 \mathrm{~d}$ after neomycin, $31.0 \mathrm{GFP}+$ cells $( \pm 22.9)$ were present in the $\mathrm{SE}$ (Fig. $3 A, F, F^{\prime}$, Table 1 ). Between 3 and $10 \mathrm{~d}$ after neomycin, numbers of GFP + cells increased fourfold (Fig. 3A-C, Table 1; $p=0.020)$. Although numbers of GFP + cells appeared to increase between 10 and $18 \mathrm{~d}$ (Fig. 3C,D, Table 1), this change was not statistically significant $(p=0.162)$. These numbers represent underestimates of the actual numbers of supporting cells with Atoh 1 transcriptional activity, since only $27 \%$ of supporting cells were transduced with the reporter virus. At all times, GFP+ cells 

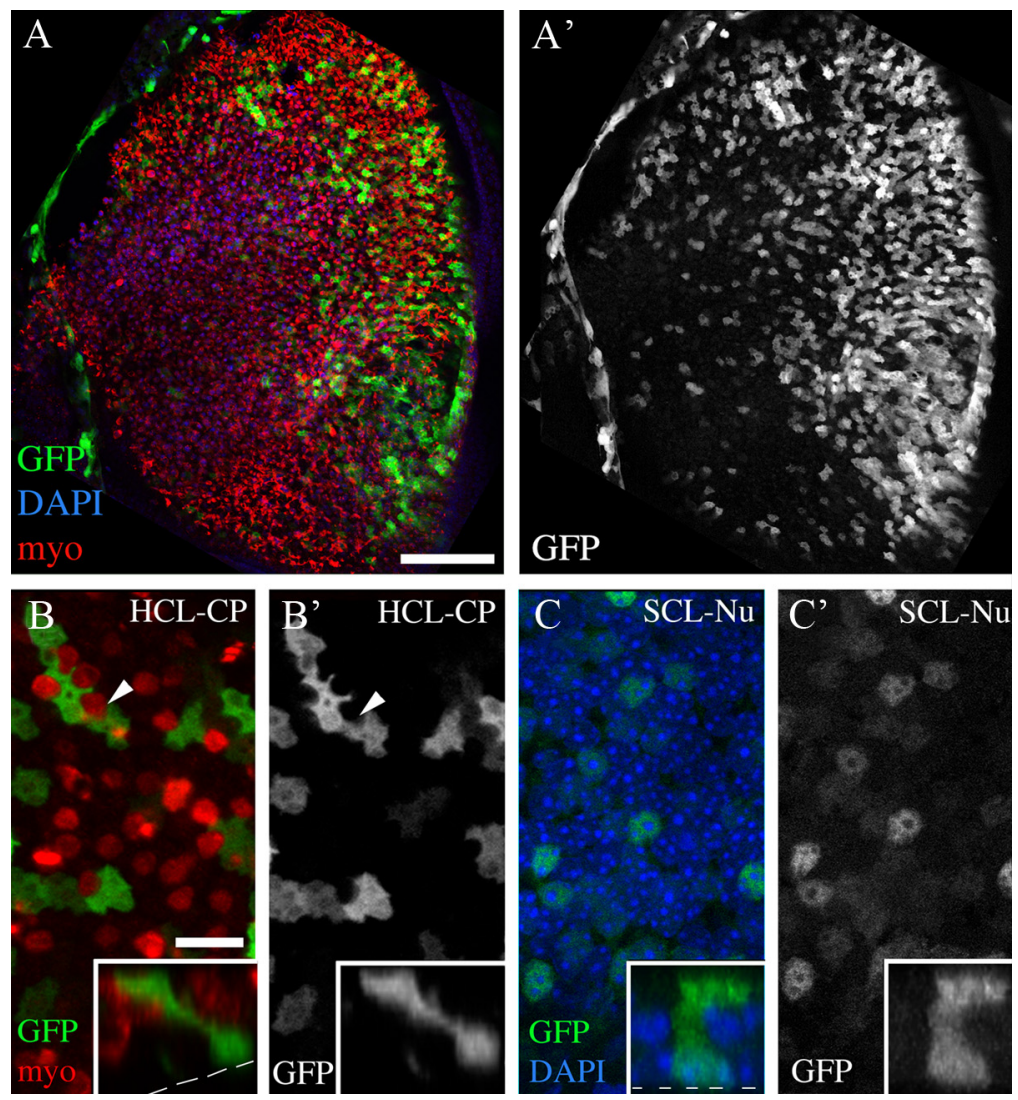

Figure 2. Adenovirus transduces supporting cells but not hair cells. All colored images show labeling for GFP (green), myosin VIlla (myo; red), and/or DAPI (blue) from utricles that were explanted, treated overnight with Ad5-CMV-GFP in media lacking neomycin, cultured for an additional day, and fixed. Individual grayscale panels show labels as indicated. $A, A^{\prime}$, Brightest point projections of $Z$-series through the SE at low magnification. $\boldsymbol{A}^{\prime}$, GFP labeling in same field as $\boldsymbol{A} . \boldsymbol{B}, \boldsymbol{B}^{\prime}, \mathrm{A}$ higher-magnification slice through the hair cell layer at the level of cuticular plate (HCL-CP), near the cell's top at the organ's lumen. $\boldsymbol{B}$, GFP and myo labeling; $\boldsymbol{B}^{\prime}$, GFP only. Arrowheads in $\boldsymbol{B}$ and $\boldsymbol{B}^{\prime}$ point to a myosin Vlla + top of a hair cell lacking GFP signal. $\boldsymbol{C}, \boldsymbol{C}^{\prime}, A$ slice through the supporting cell layer at the level of the nucleus (SCL-Nu) in the same field as $\boldsymbol{B}$ and $\boldsymbol{B}^{\prime}$. C, GFP and DAPI labeling; $\boldsymbol{C}^{\prime}$, GFP only. Insets in $\boldsymbol{B}-\boldsymbol{C}^{\prime}$ show vertical slices $(z / y)$ through two GFP + cells to illustrate their elongated shapes that are typical of supporting cells. Scale bars: $\boldsymbol{A}, \boldsymbol{A}^{\prime}$ (in $\boldsymbol{A}$ ), $100 \mu \mathrm{m} ; \boldsymbol{B}-\boldsymbol{C}^{\prime}$ (in $\left.\boldsymbol{B}\right), 6 \mu \mathrm{m}$

were distributed throughout the SE (Fig. 3G,H), suggesting that supporting cells in both extrastriolar and striolar regions reactivated Atohl after damage.

To further address Atoh1 reactivation, we labeled additional utricles with antibodies to ATOH1. Utricles from adult mice that were dissected and fixed immediately had no ATOH1 + nuclei in the SE (data not shown). Rare ATOH1 + nuclei (3-6 per SE) were detected in the SE in utricles cultured with neomycin for $1 \mathrm{~d}$ and maintained without neomycin for 2, 4, or 6 additional days (Fig. $3 E, J ; 6 \mathrm{~d}$ after neomycin is shown). These results suggest that, although many cells showed increased Atohl transcriptional activity, most of those cells may not have generated sufficient ATOH1 protein to be detected by immunolabeling, at least during the time points we examined.

Few cells with Atoh1 transcriptional activity develop hair cell features

To determine whether supporting cells with increased Atohl activity transdifferentiate into hair cells, we examined whether GFP + cells in cultures transduced with Ad5-Atoh1-GFP became immunoreactive for myosin VIIa and formed stereociliary bundles. At $3 \mathrm{~d}$ after neomycin, occasional GFP + cells $(1.7 \pm 1.9$ cells per SE) were also myosin VIIa+ (Fig. $3 I, I^{\prime}$, Table 1). There was no significant change in GFP + /myosin VIIa + cells between 3 and $10 \mathrm{~d}$ after neomycin. GFP+/myosin $\mathrm{VIIa}+$ cells increased fivefold between 10 and $18 \mathrm{~d}(p=0.001)$, but overall numbers remained very low. Most GFP +/myosin VIIa + cells had very high levels of GFP immunofluorescence and were located in the hair cell nuclear layer (Fig. $3 I, I^{\prime}$ ). In contrast, GFP + cells lacking myosin VIIa labeling usually had low or moderate levels of GFP immunofluorescence and were located in the supporting cell nuclear layer (Fig. $3 F, F^{\prime}$ ). Further, cells that were $\mathrm{GFP}+$ /myosin VIIa + were confined to the presumed striolar/juxtastriolar region (Fig. $3 H$ ) and were never seen in presumed extrastriolar regions (Fig. $3 G$ ).

Using phalloidin labeling, we could not identify stereocilia on any GFP $+/$ myosin VIIa + cells in early cultures (3-10 d after neomycin). But, at $18 \mathrm{~d}$ after neomycin, $20 \%$ of GFP $+/$ myosin VIIa + cells $(\sim 1$ GFP + cell per SE) had a short, phalloidin-positive structure resembling an immature stereociliary bundle on their apical surface ( $n=5$ utricles; data not shown, but see Fig. 5).

Since Ad5-Atoh1-GFP transduces supporting cells and not hair cells, these findings demonstrate that rare supporting cells (or existing undifferentiated hair cell precursors) in the striolar/juxtastriolar region were able to transdifferentiate into new hair cells by 2.5 weeks after neomycin treatment. We could not determine whether hair cell differentiation would continue or increase if more time were provided, because cells in the SE degenerated after longer culture periods (until $25 \mathrm{~d}$ after neomycin) (data not shown).

\section{New hair cell differentiation is promoted by inhibition of $\gamma$-secretase}

Notch signaling inhibits hair cell differentiation during embryogenesis (for review, see Kelley, 2006) and modulates hair cell regeneration in nonmammalian vertebrates (Ma et al., 2008; Daudet et al., 2009). $\gamma$-Secretase is a potent activator of the canonical notch pathway, since it cleaves the notch receptor and releases its intracellular signal-transducing domain from the plasma membrane (for review, see Kopan and Ilagan, 2009). Inhibitors of $\gamma$-secretase such as DAPT mimic notch mutations in Drosophila (Micchelli et al., 2002).

To begin to address whether notch activity blocks hair cell regeneration in the adult mouse utricle, we added $50 \mu \mathrm{M}$ DAPT to neomycin-treated cultures and looked for evidence of increased rates of renewed hair cell differentiation. Utricles were cultured overnight with Ad5-Atoh1-GFP, treated with neomycin for $1 \mathrm{~d}$, and maintained for $3,6,10$, or $18 \mathrm{~d}$ with DAPT present. GFP+ cells were seen in the SE at all times, and numbers of GFP+ cells increased significantly between 3 and $18 \mathrm{~d}$ (Fig. $3 \mathrm{~K}-\mathrm{N}$, Table 1). Overall, DAPT treatment resulted in higher numbers of GFP+ cells per SE than in DMSO controls $(p=0.001$; Fig. $4 A)$. The highest difference between DMSO and DAPT was seen at $18 \mathrm{~d}$, when 375.9 supporting cells were GFP+ in DAPT-treated 

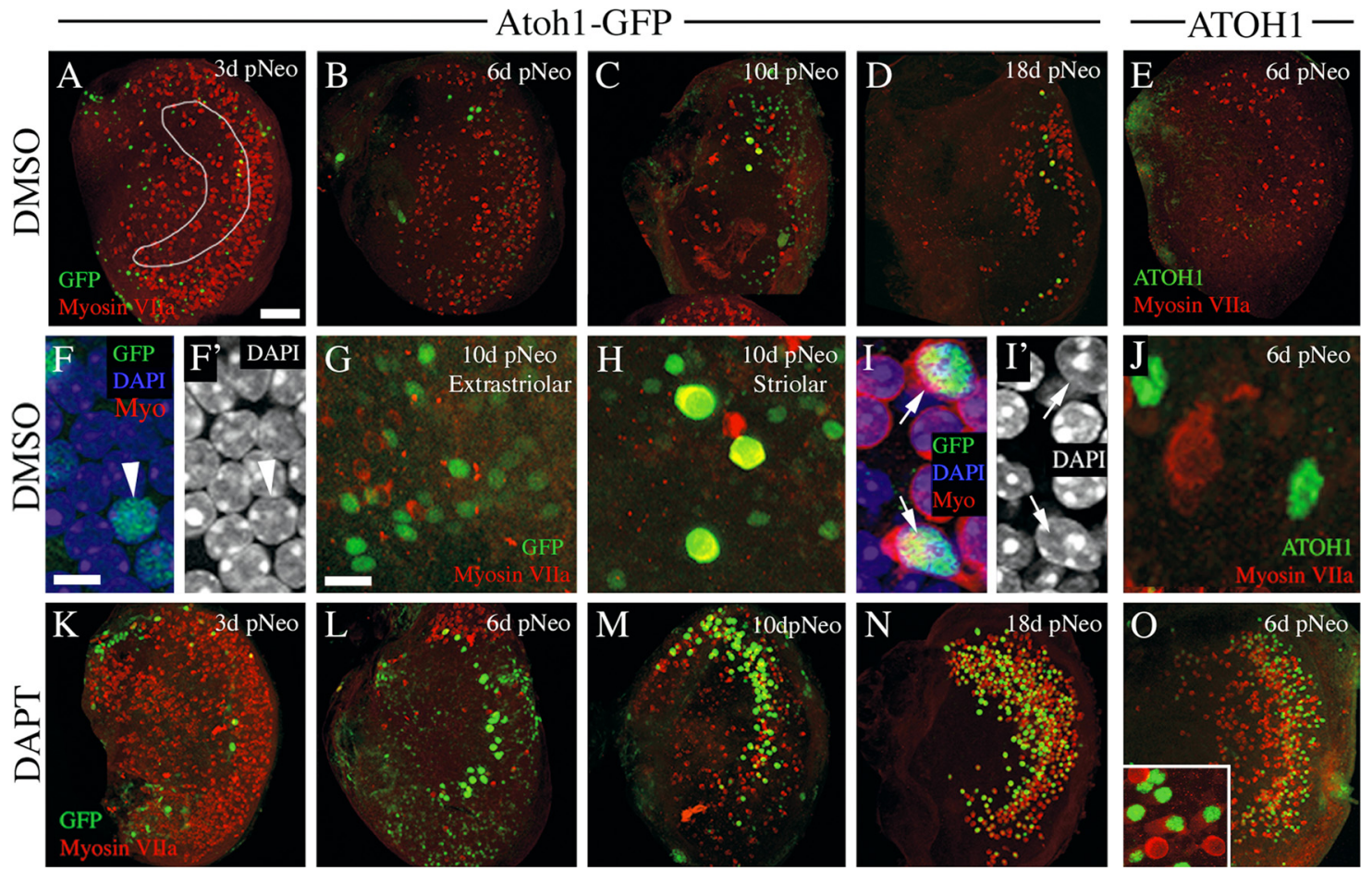

Figure 3. Low level of spontaneous hair cell regeneration following neomycin treatment is augmented by inhibition of $\gamma$-secretase: qualitative observations. All images show cultured utricles treated with neomycin for $1 \mathrm{~d}$ followed by increasing periods in culture, with $0.5 \%$ DMSO or $50 \mu$ M DAPT present in media. All images are en face $(x, y)$ views of the SE. $A-D$, Low-magnification, brightest point projections through the SE from utricles cultured for $3 \mathrm{~d}(\boldsymbol{A}), 6 \mathrm{~d}(\boldsymbol{B}), 10 \mathrm{~d}(\boldsymbol{C})$, or $18 \mathrm{~d}(\boldsymbol{D})$ after neomycin treatment (pNeo), with DMSO in the media. An outline of the approximated striolar region is drawn in $A$. GFP immunolabeling is green and myosin VIla immunolabeling is red. $E$, Low-magnification, brightest point projection through the SE cultured with DMSO until $6 \mathrm{~d}$ after neomycin. ATOH1 immunolabeling is green and myosin Vlla immunolabeling is red. $\boldsymbol{F}, \boldsymbol{F}^{\prime}$, High-magnification slice of the supporting cell nuclear layer, showing labeling for GFP (green), DAPI (blue), and myosin VIla (red) $(\boldsymbol{F})$ or DAPI only $\left(\boldsymbol{F}^{\prime}\right)$ in a DMSO-treated culture at $3 \mathrm{~d}$ after neomycin. Arrowhead points to GFP + nucleus. $\boldsymbol{G}, \boldsymbol{H}$, GFP + cells in the presumed extrastriolar region $(\boldsymbol{G})$ or striolar/juxtastriolar region $(\boldsymbol{H})$ of a DMSO-treated culture at $10 \mathrm{~d}$ after neomycin; GFP is green, and myosin VIlla is red. Double-labeled cells have yellow cytoplasm $(\boldsymbol{H}) . \boldsymbol{I}, \boldsymbol{I}^{\prime}$. High-magnification slice of the hair cell nuclear layer, showing labeling for GFP (green), myosin VIla (red), and DAPI (blue) (II) or DAPI only (I') in a DMSO-treated culture at $3 \mathrm{~d}$ after neomycin. Arrows point to myosin VIlla + cells that have GFP + nuclei. J, High-magnification, brightest point projection through the SE cultured with DMSO until $6 \mathrm{~d}$ after neomycin. ATOH1 immunolabeling is green and myosin VIla immunolabeling is red. $\boldsymbol{K}-\boldsymbol{N}$, Low-magnification, brightest point projections through the SE from utricles cultured for $3 \mathrm{~d}(\boldsymbol{K}), 6 \mathrm{~d}(\boldsymbol{L}), 10 \mathrm{~d}(\boldsymbol{M})$, or $18 \mathrm{~d}(\boldsymbol{N})$ after neomycin treatment, with DAPT present for the whole culture period. GFP immunolabeling is green and myosin VIla immunolabeling is red. $\mathbf{0}$, Low-magnification, brightest point projection through the SE cultured with DAPT until $6 \mathrm{~d}$ after neomycin. ATOH1 immunolabeling is green and myosin VIla immunolabeling is red. All low-magnification utricle images are oriented in the same manner as shown in Figure $1 E$. Scale bars: $A-E, K-\mathbf{O}$ (in $\boldsymbol{A}$ ), $100 \mu \mathrm{m} ; \boldsymbol{F}, \boldsymbol{F}^{\prime}, \boldsymbol{I}, \boldsymbol{I}^{\prime}, \boldsymbol{J}$ (in $\left.\boldsymbol{F}\right), 5 \mu \mathrm{m} ; \boldsymbol{G}, \boldsymbol{H}$, inset in $\mathbf{O}$ (in $\mathbf{G}$ ), $10 \mu \mathrm{m}$.

utricles, which was twofold more than in DMSO controls. In DAPT-treated cultures, moderately GFP + cells were seen in presumed striolar and extrastriolar regions, similar to the DMSOtreated cultures.

DAPT treatment caused a dramatic increase in the number of cells that were highly GFP+ and the number of cells that were $\mathrm{GFP}+$ /myosin VIIa + compared to DMSO controls $(p<0.001)$ (Figs. $3 K-N, 4 B, C$, Table 1). At 18 d, DAPT-treated cultures had nearly 30 -fold more GFP +/myosin VIIa + cells than DMSO controls. Further, $\sim 50 \%$ of the GFP + /myosin VIIa + cells had distinct bundles of stereocilia (e.g., Fig. $5 ; n=6$ utricles), a higher proportion than seen in DMSO controls at this time $(\sim 20 \%)$. Similar to DMSO-treated cultures, the cells that were highly GFP + and myosin VIIa + were most pronounced in what appeared to be the striolar/juxtastriolar region (Fig. $3 K-N$ ), based on the position and reverse C-shaped pattern of GFP labeling.

Pro-regenerative effects of DAPT were also seen at a lower DAPT concentration. Utricles $(n=4)$ treated with $10 \mu \mathrm{M}$ DAPT for $6 \mathrm{~d}$ had $153.3( \pm 54.3) \mathrm{GFP}+$ cells while utricles cultured with DMSO had $67.7( \pm 49.4 ; n=9$ utricles $)$. This difference was statistically significant $(p=0.017)$. Further, utricles cultured with $10 \mu \mathrm{M}$ DAPT had significantly more GFP + /myosin VIIa + cells $(9.5 \pm 11.1)$ compared to utricles cultured with DMSO $(0.2 \pm 0.4)(p=0.003)$.
We also examined changes in ATOH1 protein in response to $\gamma$-secretase inhibition. Utricles were cultured with neomycin for $1 \mathrm{~d}$ followed by 2, 4, or $6 \mathrm{~d}$ with $50 \mu \mathrm{M}$ DAPT (Fig. 3O). DAPT treatment caused significantly higher numbers of cells with nuclear ATOH1 compared to DMSO ( $p=0.045$; Fig. 3 , compare $O$ with $E$; Fig. $4 D$ ). Further, at 4 and $6 \mathrm{~d}$ after neomycin, the distribution of ATOH1 + cells was reverse C-shaped, similar to Atoh1GFP in DAPT-treated cultures at 6-18 d. These observations helped to validate Ad5-Atoh1-GFP as an accurate reporter for Atohl transcriptional activity. The number of ATOH1 + cells that were myosin $\mathrm{VIIa}+$ also showed a significant increase between 2 and $6 \mathrm{~d}(p=0.020)$ in DAPT-treated utricles, in contrast to the decline seen in DMSO controls during this period $(p=0.010)$ (Fig. 4E).

These findings demonstrate that $\gamma$-secretase inhibitors induced more supporting cells to activate Atohl transcription and pushed more supporting cells to progress to advanced stages of hair cell differentiation after in vitro neomycin treatment than occurs in DMSO controls.

\section{Hair cell regeneration is initiated cultures without neomycin treatment}

As shown in Figure 1, utricles cultured without neomycin showed spontaneous loss of hair cells, although numbers were reduced 


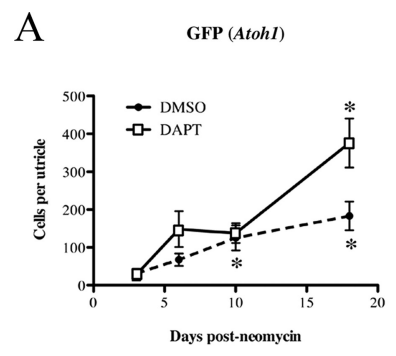

B

High GFP (AtohI) $\quad$ C

C GFP (AtohI)/Myosin VIIa
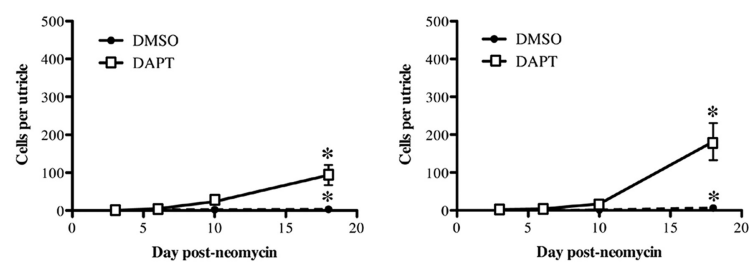

$\mathrm{D}$

АTOH1

E

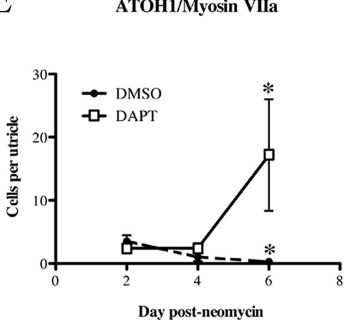

Figure 4. Low level of spontaneous hair cell regeneration following neomycin treatment is augmented by inhibition of $\gamma$-secretase: quantitative observations. Graphs show average numbers ( \pm SEM) of SE cells per utricle for the following groups: GFP $($ Atoh1) + cells (A), highly GFP (Atoh1) + cells (B), GFP (Atoh1) +/myosin Vlla + cells (C), ATOH1 + cells (D), or ATOH1 +/myosin $\mathrm{VIla}+$ cells $(\boldsymbol{E})$. All data were derived from neomycin-treated utricles. The $x$-axis indicates the time after neomycin, and the $y$-axis indicates the number of cells per utricle (SE). For $\boldsymbol{A}-\boldsymbol{C}$, numbers of utricles examined at each time point are given in Table 1. For $\boldsymbol{D}$ and $\boldsymbol{E}$, cell counts were performed on the following number of utricles for the DMSO treatment group ( $n=4$ utricles at $2 \mathrm{~d}, 6$ at $4 \mathrm{~d}$, and 4 at $6 \mathrm{~d}$ ) and the DAPT treatment group ( $n=7$ utricles at $2 \mathrm{~d}, 12$ at $4 \mathrm{~d}$, and 6 at $6 \mathrm{~d}$ ). Asterisks in $\boldsymbol{A}-\boldsymbol{C}$ denote statistically significant difference from $3 \mathrm{~d}$ after neomycin, and asterisks in $\boldsymbol{D}$ and $\boldsymbol{E}$ denote statistically significant difference from $2 \mathrm{~d}$ after neomycin, with each treatment group. Differences between treatment groups are discussed in the Results section.

tion by pushing more supporting cells to enter the cell cycle, we assessed BrdU uptake in utricles that were explanted, cultured with neomycin for $1 \mathrm{~d}$, and maintained with $50 \mu \mathrm{M}$ DAPT or $0.5 \%$ DMSO for 4,6 , or 10 more days $(n=6-8$ utricles per group). BrdU was present in media for the entire culture period after neomycin treatment. In addition, we examined BrdU labeling in utricles that were explanted, cultured with neomycin for $1 \mathrm{~d}$, and maintained with $50 \mu \mathrm{M}$ DAPT or $0.5 \%$ DMSO for $21 \mathrm{~d}$, with BrdU present for the last $7 \mathrm{~d}(n=4-6$ utricles per group). Although BrdU+ nuclei were abundant throughout the connective tissue underlying the SE in all utricles examined, they were extremely rare in the SE of DMSO- or DAPT-treated utricles (1-2 cells per SE were seen at most, regardless of the BrdU labeling paradigm; data not shown). These findings demonstrated that inhibition of $\gamma$-secretase did not trigger significant mitotic activity in supporting cells.

If supporting cells give rise to new hair cells by direct conversion, one would predict that ATOH1 would first accumulate in supporting cells and would subse-

compared to neomycin-treated utricles. To determine whether this degree of loss was sufficient to trigger hair cell regeneration, utricles were cultured overnight with Ad5-Atoh1-GFP followed by $4 \mathrm{~d}$ in media containing $0.5 \%$ DMSO or $50 \mu \mathrm{M}$ DAPT but no neomycin. In DMSO-treated cultures, there were $24.8( \pm 22.4)$ GFP + cells in the SE, and in DAPT-treated cultures, there were 34.8 ( \pm 12.6$)$ (Table 1$)$. There was no statistically significant difference between these two groups $(p=0.466)$. In contrast, significantly more SE cells were GFP +/myosin VIIa + in the DAPT group $(7.5 \pm 3.0)$ than in the DMSO group $(0.5 \pm 0.6)(p=$ 0.004 ) (Table 1). In both cases, GFP + /myosin VIIa + cells appeared to be confined to the striola/juxtastriolar region (data not shown). We compared these data to those obtained from utricles cultured with DAPT or DMSO for the same period after a $1 \mathrm{~d}$ treatment with neomycin (Table 1). Neomycin treatment had no significant effect on numbers of GFP + cells $(p=0.657)$ or GFP $+/$ myosin $\mathrm{VIIa}+$ cells in cultures containing DMSO alone $(p=0.272)$ or on $\mathrm{GFP}+$ cells in cultures with DAPT $(p=0.764)$. However, significantly more GFP+/myosin VIIa + cells were seen in DAPT-treated cultures when neomycin was omitted than when neomycin was present $(7.5 \pm 3.0$ vs $2.3 \pm 1.8 ; p=0.005)$.

These findings indicate that a similar degree of new hair cell differentiation was initiated in adult mouse utricles regardless of whether hair cell loss was induced by neomycin or by changes associated with culturing. In contrast, DAPT seems to promote more overt hair cell differentiation when neomycin is absent.

\section{$\gamma$-Secretase inhibition promotes conversion of supporting cells into hair cells without cell division}

In nonmammals that readily regenerate hair cells, new hair cells arise from supporting cells via two mechanisms: renewed mitosis or direct conversion (transdifferentiation) without mitosis (for review, see Stone and Cotanche, 2007; Brignull et al., 2009). To determine whether $\gamma$-secretase promotes new hair cell regenera- quently switch to hair cells as the conversion is occurring. In support of this, we found that $74 \%( \pm 31 \%)$ of ATOH $1+$ nuclei were located in the supporting cell nuclear layer at $4 \mathrm{~d}$ after neomycin, and this number dropped to $7 \%( \pm 6 \%)$ at $6 \mathrm{~d}(p=0.006)$. These observations suggest that supporting cells upregulate ATOH1 and then transit into the hair cell layer and differentiate additional hair cell features. A similar trend over time was seen with the Atoh1 adenoviral reporter.

These findings demonstrate that inhibition of $\gamma$-secretase after in vitro hair cell damage increases the number of supporting cells in adult mouse utricles that reactivate Atoh 1 and undergo phenotypic conversion into hair cell-like cells without dividing.

\section{Transcription of notch target genes is disrupted following $\gamma$-secretase inhibition}

$\gamma$-Secretase has several substrates (Beel and Sanders, 2008). Hence, it is unclear whether the effects we observed with DAPT were a direct result of inhibiting notch signaling. To address this question, we first used qRTPCR to examine whether notch pathway transcripts are detected in utricles cultured with neomycin for $1 \mathrm{~d}$ followed by $3 \mathrm{~d}$ with $0.5 \%$ DMSO. Transcripts for Dll1 and Jag2 were most abundant, at one-fifth to one-third the level of $\beta$-actin, respectively (Fig. 6A). Transcripts for Notch1-4, Hes1, Hey1, and Hey3 were less abundant $(\sim 1 / 1000$ of $\beta$-actin $)$. Hes5 transcripts were very low $(\sim 1 / 10,000$ the level of $\beta$-actin $)$. For comparison, Hes 5 transcripts were $1 / 1000$ the level of $\beta$-actin in P1 mouse brain (data not shown). We also detected immunoreactivity for Jag 1 in a pattern resembling that described by Oesterle et al. (2008) (data not shown). These findings demonstrate that notch pathway genes are expressed in adult mouse utricles after in vitro hair cell damage.

Next, we examined whether DAPT treatment causes a decrease in transcripts for notch targets, Hes1, Hey1, and Hey3, which is predicted if DAPT reduces notch activity. Utricles were 
cultured for $3 \mathrm{~d}$ with either 0.5\% DMSO or $50 \mu \mathrm{M}$ DAPT after an initial $1 \mathrm{~d}$ treatment with neomycin. DAPT significantly reduced transcripts for Hesl, Heyl, and Hey3, compared to DMSO $(p=0.035)$ (Fig. $6 B)$. This finding supports the hypothesis that DAPT promotes hair cell regeneration in adult mouse utricles by inhibiting notch activity.

\section{Hair cell regeneration increases upon inhibition of TACE}

If DAPT's positive effects on hair cell regeneration are indeed notch dependent, then inhibition of a second enzyme required for notch activity should have similar effects. To test this hypothesis, utricles were explanted, transduced with Ad5Atoh1-GFP, cultured for $1 \mathrm{~d}$ with neomycin, and then cultured with $50 \mu \mathrm{M}$ TAPI-1, which inhibits a second notch-cleaving enzyme TACE, for 6 additional days. Utricles treated with TAPI-1 had 144.8 $( \pm 79.1) \mathrm{GFP}+$ cells per SE, while those treated with DMSO had $67.7( \pm 49.4)$ GFP + cells per SE $(p=0.036)(n=6$ utricles for TAPI-1 and 9 utricles for DMSO). Utricles cultured with TAPI-1 also had significantly more GFP +/myosin VIIa + cells per SE $(2.0 \pm 1.4)$ than those treated with DMSO $(0.2 \pm 0.4)(p=$ $0.003)$, with a similar focus in the striolar region as DAPT-treated utricles. Although TAPI-1 had a less pronounced effect on promoting differentiation of myosin VIIa immunoreactivity than DAPT, these results are consistent with the interpretation that inactivation of notch signaling promotes new hair cell differentiation in the adult mouse utricle following damage.

\section{Discussion}

Hair cell differentiation is reactivated in the adult mouse utricle after hair cell damage in vitro

In mammals, it is well established that hair cells are not replaced in adult cochleae after systemic ototoxin treatment (e.g., Roberson and Rubel, 1994; Forge et al., 1998). However, some degree of hair cell replacement does occur in mature mammalian utricles. Forge et al. (1993, 1998) described the emergence of immatureappearing hair cells after gentamicin-induced hair cell loss in adult guinea pig utricles and a subsequent increase in more mature-appearing hair cells. A similar finding was reported for the adult mouse utricle by Kawamoto et al. (2009). Immature hair cells were detectable by the second week after damage by their short stereociliary bundles or cytoplasmic properties (e.g., dense polyribosomes) in electron micrographs. The relative contributions of cellular repair and regeneration to the return of the hair cell profiles following damage is unclear. The ambiguity exists in part because it is difficult to completely rid the utricle of original hair cells using in vivo drug treatments, and some capacity for repair of injured hair cells has been documented (Sobkowicz et al., 1992; Zheng et al., 1999; Gale et al., 2002). Further, while studies have strategically chronicled the loss of gross, ultrastructural, or molecular evidence for original hair cells, they have

\section{8d pNeo+DAPT}
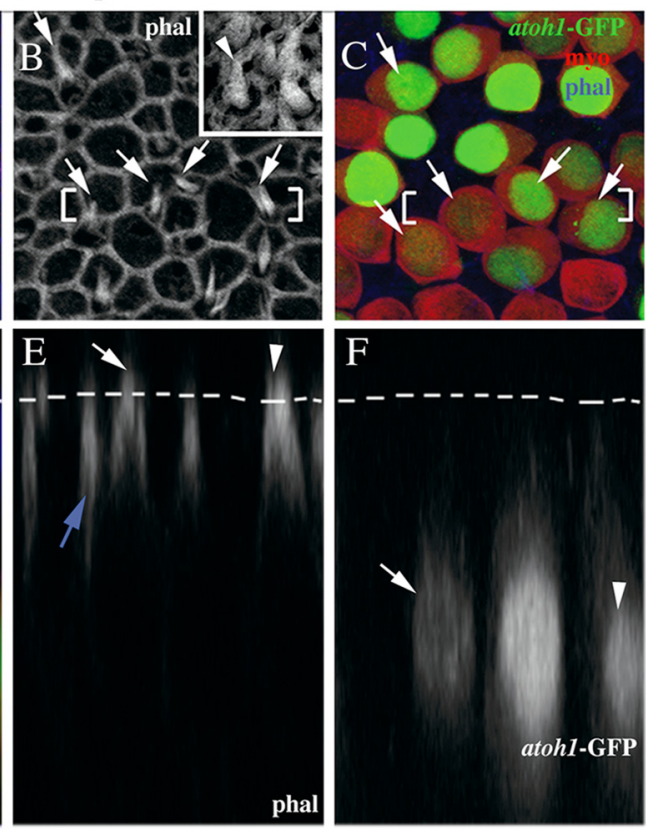

Figure 5. Newly differentiated hair cells have immature bundles of stereocilia. $\boldsymbol{A}-\boldsymbol{C}$, The same field of the presumed striolar region of a utricle cultured with DAPT for $18 \mathrm{~d}$ after neomycin treatment. $\boldsymbol{A}, \boldsymbol{B}, 0 \mathrm{ptical}$ slices through the lumenal surface of the $S E$ nuct (hilia) that project above the lumenal surface. The arrow and arrowhead in $\boldsymbol{F}$ point to the nuclei from the same cells as indicated by the arrow and arrowhead in $\boldsymbol{D}$ and $\boldsymbol{E}$. The blue arrows in $\boldsymbol{D}$ and $\boldsymbol{E}$ indicate a phalloidin-labeled tight junction that lies below the lumenal surface connecting two myosin VIla - supporting cells. Scale bar, $5 \mu \mathrm{m}$ for all panels and insets.

not systematically examined the reactivation of early developmental gene programs that would presumably accompany production of new hair cells as opposed to hair cell repair.

In the current study, we used an in vitro damage method to kill most original hair cells in the adult mouse utricle. We looked for molecular evidence of new hair cell differentiation by tracking transcriptional reactivation of the basic helix-loop-helix transcription factor, Atoh1. During inner ear development, Atoh1 is transcribed at a low level in progenitor cells (Woods et al., 2004), but it becomes pronounced in nascent embryonic hair cell cells (Bermingham et al., 1999; Woods et al., 2004), which then accumulate ATOH1 protein (Chen et al., 2002). Once hair cells have matured, Atoh1 transcription is severely reduced (Shailam et al., 1999; Woods et al., 2004). Damage to hair cells, caused by either neomycin treatment or culture conditions, triggered many supporting cells to increase Atoh 1 enhancer activity as early as $4 \mathrm{~d}$ in vitro and continuing over a 3 week culture period. However, only a small fraction of cells accumulated ATOH1 protein, acquired high levels of myosin VIIa, a marker of mature hair cells, or developed a stereociliary bundle. Therefore, although numerous supporting cells in the adult mouse utricle spontaneously reactivate a developmental gene program characteristic of early differentiating hair cells after damage, only rare cells acquire features typical of mature hair cells during a 3 week period in culture. Our observations are consistent with findings by Forge et al. (1993) and Kawamoto et al. (2009), even after months of recovery from aminoglycoside treatment 
A

\begin{tabular}{|c|c|}
\hline $\begin{array}{c}\text { Gene } \\
\text { name }\end{array}$ & $\begin{array}{c}\text { Average } \mathbf{2}^{\text {-dCt }} \\
( \pm \text { S.D. })\end{array}$ \\
\hline Notch1 & $.0082( \pm .0043)$ \\
\hline Notch 2 & $.0021( \pm .0009)$ \\
\hline Notch 3 & $.0035( \pm .0060)$ \\
\hline Notch 4 & $.0031( \pm .0060)$ \\
\hline Dll1 & $.1762( \pm .2039)$ \\
\hline Jag2 & $.3192( \pm .4322)$ \\
\hline Hes1 & $.0062( \pm .0079)$ \\
\hline Hes5 & $.0004( \pm .0005)$ \\
\hline Hey1 & $.0032( \pm .0034)$ \\
\hline Hey3 & $.0036( \pm .0036)$ \\
\hline
\end{tabular}

B

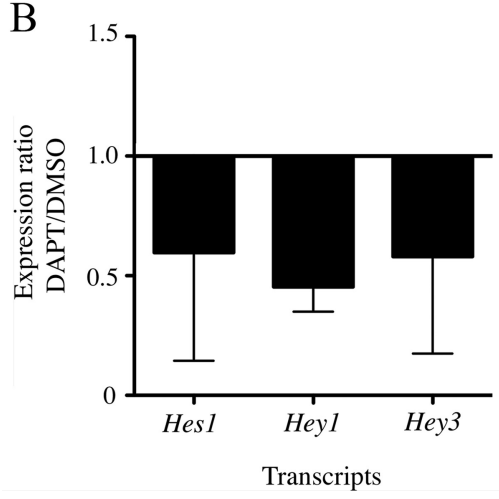

Figure 6. Transcription of notch target genes is significantly altered by $\gamma$-secretase inhibition. All data in this figure were obtained by qRTPCR. $A$, The table shows average $2^{-\mathrm{dct}}$, or gene expression level relative to $\beta$-actin, for several notch pathway genes in utricles treated with 4 тм neomycin for $1 \mathrm{~d}$ followed by $3 \mathrm{~d}$ with $0.5 \%$ DMSO. $\boldsymbol{B}$, Graph shows the expression ratio for DAPT relative to DMSO $\left(2^{-\mathrm{dct}}\right.$ for DAPT divided by $2^{-\mathrm{dct}}$ for DMSO). Utricles were cultured for $1 \mathrm{~d}$ with $4 \mathrm{~mm}$ neomycin then for $3 \mathrm{~d}$ with either $0.5 \%$ DMSO or $50 \mu \mathrm{m}$ DAPT. Bars show SDs. Experimental numbers are provided in Materials and Methods.

in vivo. However, our findings are in stark contrast to the response of the mature avian utricular or auditory SE to in vitro hair cell loss, where hundreds of new hair cells differentiate within days of damage (Matsui et al., 2000; Shang et al., 2010; Warchol and Montcouquiol, 2010).

\section{Hair cell regeneration is antagonized by notch activity}

We investigated whether levels of hair cell regeneration can be improved by inhibiting the notch pathway. Recent studies in two species of animals that naturally regenerate hair cells_- chickens and zebrafish - showed that notch activity is upregulated in inner ear sensory epithelia and lateral line neuromasts after hair cell damage, where it modulates the number of new hair cells that are ultimately regenerated (Ma et al., 2008; Daudet et al., 2009). We demonstrate that inhibition of $\gamma$-secretase with DAPT significantly reduced notch signaling in adult mouse utricles and increased Atoh1 transcriptional activity, specifically in supporting cells. More importantly, DAPT pushed more supporting cells to progress to later stages of hair cell differentiation, including development of stereociliary bundles. We found similar results with an inhibitor of TACE, a second enzyme required for notch activity. These findings implicate a role for notch-mediated lateral inhibition in antagonizing hair cell regeneration in adult mouse utricles. Additional studies are required to characterize how notch exerts this antagonistic influence. It is important to note is that inhibition of notch signaling with DAPT did not prevent or limit regeneration of hair cells, which is similar to what has been reported for nonmammals (Ma et al., 2008; Daudet et al., 2009).
Therefore, notch activation is not required to prime supporting cells to transdifferentiate into hair cells, as one might hypothesize given notch's role in specifying hair cell progenitors during inner ear development (Daudet and Lewis, 2005; Kiernan et al., 2006; Daudet et al., 2007; Hayashi et al., 2008; Hartman et al., 2010).

\section{Notch activity blocks a nonmitotic form of transdifferentiation}

Several observations indicate that supporting cells form new hair cells after damage, in the presence or absence of notch activity, by direct transdifferentiation, or conversion into hair cells without cell division. First, the adenoviral Atoh1-GFP reporter that we used was delivered only to supporting cells, and GFP was later detected in hair cells. Second, ATOH1 + cells transitioned over time from the supporting cell layer into the hair cell layer and went from being myosin VIIa - to myosin VIIa+. Third, very little BrdU uptake was seen in supporting cells cultured with either DMSO or DAPT. Our conclusion that utricular hair cell regeneration is primarily nonmitotic is consistent with studies of adult rodent utricles after in vivo hair cell damage (e.g., Forge et al., 1993; Kawamoto et al., 2009).

\section{Regional variation in supporting cell responses and regulation}

Spontaneous differentiation of new hair cells was limited to the area in and around the striola, despite widespread hair cell loss throughout the utricular SE. Inhibition of $\gamma$-secretase or TACE caused increased hair cell regeneration in this same place, but not elsewhere. We do not yet know which notch ligands or effectors antagonize hair cell regeneration in the striola. Hartman et al. (2009) showed that Hes5-GFP fluorescence is pronounced in extrastriolar regions in control utricles, but we detected extremely low levels of Hes5 transcripts. Moreover, hair cell regeneration was not increased in regions correlated with high Hes5 GFP fluorescence after $\gamma$-secretase inhibition. These findings suggest that other HEY/HES proteins beside HES5 must antagonize hair cell regeneration in the striola. Our results also suggest notch signaling does not play a prominent role in attenuating hair cell regeneration in extrastriolar regions. However, it is also possible that signals promoting hair cell regeneration are insufficient in extrastriolar regions or additional inhibitory pathways are active there. These regional differences provide opportunities to learn about other signals controlling hair cell regeneration in the inner ear.

\section{Hair cell damage in culture}

Aminoglycoside treatment has been used previously to induce hair cell loss in cultured rodent utricles (e.g., Warchol et al., 1993; Cunningham et al., 2002). We found that $1 \mathrm{~d}$ treatments with high-dose ( $4 \mathrm{~mm}$ ) neomycin caused $88 \%$ loss of hair cells in mouse utricles by $4 \mathrm{~d}$ in vitro. Incomplete hair cell loss makes it more challenging to rule out hair cell repair. However, we resisted using higher-dose neomycin, because we worried that it would be directly toxic to supporting cells and disrupt regeneration. Complete hair cell loss is not required to induce regenerative responses in supporting cells. This is illustrated by our findings in cultures lacking neomycin as well as in other studies (e.g., Oesterle et al., 1993; Yamashita and Oesterle, 1995). Our observation that Atoh1 is reactivated in supporting cells after hair cell damage, whether it be druginduced or culture-induced, strengthens the evidence that hair cell damage consistently triggers some supporting cells in adult mouse utricles to begin to convert into hair cells. 
Incomplete hair cell lesions could be advantageous for hair cell regeneration studies for the following reasons: they may better represent the types of lesions seen in humans with hearing or balance disorders, and they may involve less damage to supporting cells and accessory tissues in the inner ear, enabling better regenerative responses. Consistent with this latter idea, we found that $\gamma$-secretase inhibition promoted more overt hair cell differentiation in the absence of neomycin.

\section{References}

Amalfitano A, Chamberlain JS (1997) Isolation and characterization of packaging cell lines that coexpress the adenovirus E1, DNA polymerase, and preterminal proteins: implications for gene therapy. Gene Ther 4:258263.

Beel AJ, Sanders CR (2008) Substrate specificity of gamma-secretase and other intramembrane proteases. Cell Mol Life Sci 65:1311-1334.

Bermingham NA, Hassan BA, Price SD, Vollrath MA, Ben-Arie N, Eatock RA, Bellen HJ, Lysakowski A, Zoghbi HY (1999) Math1: an essential gene for the generation of inner ear hair cells. Science 284:1837-1841.

Brignull HR, Raible DW, Stone JS (2009) Feathers and fins: nonmammalian models for hair cell regeneration. Brain Res 1277:12-23.

Cafaro J, Lee GS, Stone JS (2007) ATOH1 expression defines activated progenitors as well as differentiating hair cells during avian hair cell regeneration. Dev Dyn 236:156-170.

Chen P, Johnson JE, Zoghbi HY, Segil N (2002) The role of Math1 in inner ear development: uncoupling the establishment of the sensory primordium from hair cell fate determination. Development 129:2495-2505.

Cunningham LL, Cheng AG, Rubel EW (2002) Caspase activation in hair cells of the mouse utricle exposed to neomycin. J Neurosci 22:8532-8540.

Daudet N, Lewis J (2005) Two contrasting roles for notch activity in chick inner ear development: specification of prosensory patches and lateral inhibition of hair-cell differentiation. Development 132:541-551.

Daudet N, Ariza-McNaughton L, Lewis J (2007) Notch signaling is needed to maintain, but not to initiate, the formation of prosensory patches in the chick inner ear. Development 134:2369-2378.

Daudet N, Gibson R, Shang J, Bernard A, Lewis J, Stone J (2009) Notch regulation of progenitor cell behavior in quiescent and regenerating auditory epithelium of mature birds. Dev Biol 326:86-100.

Desai SS, Zeh C, Lysakowski A (2005) Comparative morphology of rodent vestibular periphery. I. Saccular and utricular maculae. J Neurophysiol 93:251-266.

Forge A, Li L, Corwin JT, Nevill G (1993) Ultrastructural evidence for hair cell regeneration in the mammalian inner ear. Science 259:1616-1619.

Forge A, Li L, Nevill G (1998) Hair cell recovery in the vestibular sensory epithelia of mature guinea pigs. J Comp Neurol 397:69-88.

Gale JE, Meyers JR, Periasamy A, Corwin JT (2002) Survival of bundleless hair cells and subsequent bundle replacement in the bullfrog's saccule. J Neurobiol 50:81-92.

Gubbels SP, Woessner DW, Mitchell JC, Ricci AJ, Brigande JV (2008) Functional auditory hair cells produced in the mammalian cochlea by in utero gene transfer. Nature 455:537-541.

Hartman BH, Basak O, Nelson BR, Taylor V, Bermingham-McDonogh O, Reh TA (2009) Hes5 expression in the postnatal and adult mouse inner ear and the drug-damaged cochlea. J Assoc Res Otolaryngol 10:321-340.

Hartman BH, Reh TA, Bermingham-McDonogh O (2010) Notch signaling specifies prosensory domains via lateral induction in the developing mammalian inner ear. Proc Natl Acad Sci U S A 107:15792-15797.

Hasson T, Gillespie PG, Garcia JA, MacDonald RB, Zhao Y, Yee AG, Mooseker MS, Corey DP (1997) Unconventional myosins in inner-ear sensory epithelia. J Cell Biol 137:1287-1307.

Hayashi T, Kokubo H, Hartman BH, Ray CA, Reh TA, BerminghamMcDonogh O (2008) Hesr1 and Hesr2 may act as early effectors of notch signaling in the developing cochlea. Dev Biol 316:87-99.

Helms AW, Johnson JE (1998) Progenitors of dorsal commissural interneurons are defined by MATH1 expression. Development 125:919-928.

Helms AW, Abney AL, Ben-Arie N, Zoghbi HY, Johnson JE (2000) Autoregulation and multiple enhancers control Math1 expression in the developing nervous system. Development 127:1185-1196.

Holt JR, Johns DC, Wang S, Chen ZY, Dunn RJ, Marban E, Corey DP (1999) Functional expression of exogenous proteins in mammalian sensory hair cells infected with adenoviral vectors. J Neurophysiol 81:1881-1888.
Hori R, Nakagawa T, Sakamoto T, Matsuoka Y, Takebayashi S, Ito J (2007) Pharmacological inhibition of notch signaling in the mature guinea pig cochlea. Neuroreport 18:1911-1914.

Huang Y, Chi F, Han Z, Yang J, Gao W, Li Y (2009) New ectopic vestibular hair cell-like cells induced by Math1 gene transfer in postnatal rats. Brain Res 1276:31-38.

Kageyama R, Ohtsuka T, Hatakeyama J, Ohsawa R (2005) Roles of bHLH genes in neural stem cell differentiation. Exp Cell Res 306:343-348.

Kawamoto K, Ishimoto S-I, Minoda R, Brough DE, Raphael Y (2003) Math1 gene transfer generates new cochlear hair cells in mature guinea pigs in vivo. J Neurosci 23:4395-4400.

Kawamoto K, Izumikawa M, Beyer LA, Atkin GM, Raphael Y (2009) Spontaneous hair cell regeneration in the mouse utricle following gentamicin ototoxicity. Hear Res 247:17-26.

Kelley MW (2006) Regulation of cell fate in the sensory epithelia of the inner ear. Nat Rev Neurosci 7:837-849 [Erratum (2007) 8:239].

Kiernan AE, Xu J, Gridley T (2006) The notch ligand JAG1 is required for sensory progenitor development in the mammalian inner ear. PLoS Genet 2:e4.

Kirkegaard M, Nyengaard JR (2005) Stereological study of postnatal development in the mouse utricular macula. J Comp Neurol 492:132-144.

Kopan R, Ilagan MX (2009) The canonical notch signaling pathway: unfolding the activation mechanism. Cell 137:216-233.

Kuntz AL, Oesterle EC (1998) Transforming growth factor alpha with insulin stimulates cell proliferation in vivo in adult rat vestibular sensory epithelium. J Comp Neurol 399:413-423.

Lanford PJ, Shailam R, Norton CR, Gridley T, Kelley MW (2000) Expression of Math1 and HES5 in the cochleae of wildtype and Jag2 mutant mice. J Assoc Res Otolaryngol 1:161-171.

Lewis J (1998) notch signaling and the control of cell fate choices in vertebrates. Semin Cell Dev Biol 9:583-589.

Li A, Xue J, Peterson EH (2008) Architecture of the mouse utricle: macular organization and hair bundle heights. J Neurophysiol 99:718-733.

Lumpkin EA, Collisson T, Parab P, Omer-Abdalla A, Haeberle H, Chen P, Doetzlhofer A, White P, Groves A, Segil N, Johnson JE (2003) Math1driven GFP expression in the developing nervous system of transgenic mice. Gene Expr Patterns 3:389-395.

Luo J, Deng ZL, Luo X, Tang N, Song WX, Chen J, Sharff KA, Luu HH, Haydon RC, Kinzler KW, Vogelstein B, He TC (2007) A protocol for rapid generation of recombinant adenoviruses using the AdEasy system. Nat Protoc 2:1236-1247.

Ma EY, Rubel EW, Raible DW (2008) notch signaling regulates the extent of hair cell regeneration in the zebrafish lateral line. J Neurosci 28:2261-2273.

Matsui JI, Oesterle EC, Stone JS, Rubel EW (2000) Characterization of damage and regeneration in cultured avian utricles. J Assoc Res Otolaryngol $1: 46-63$.

Micchelli CA, Esler WP, Kimberly WT, Jack C, Berezovska O, Kornilova A, Hyman BT, Perrimon N, Wolfe MS (2002) Gamma-secretase/presenilin inhibitors for Alzheimer's disease phenocopy Notch mutations in Drosophila. FASEB J 17:79-81.

Oesterle EC, Tsue TT, Reh TA, Rubel EW (1993) Hair-cell regeneration in organ cultures of the postnatal chicken inner ear. Hear Res 70:85-108.

Oesterle EC, Campbell S, Taylor RR, Forge A, Hume CR (2008) Sox2 and JAGGED1 expression in normal and drug-damaged adult mouse inner ear. J Assoc Res Otolaryngol 9:65-89.

Pfaffl MW (2001) A new mathematical model for relative quantification in real-time RT-PCR. Nucleic Acids Res 29:e45.

Roberson DW, Rubel EW (1994) Cell division in the gerbil cochlea after acoustic trauma. Am J Otol 15:28-34.

Rubel EW, Dew LA, Roberson DW (1995) Mammalian vestibular hair cell regeneration. Science 267:701-707.

Ruben RJ (1967) Development of the inner ear of the mouse: a radioautographic study of terminal mitoses. Acta Otolaryngol [Suppl] 220:1-44.

Shailam R, Lanford PJ, Dolinsky CM, Norton CR, Gridley T, Kelley MW (1999) Expression of proneural and neurogenic genes in the embryonic mammalian vestibular system. J Neurocytol 28:809-819.

Shang J, Cafaro J, Nehmer R, Stone J (2010) Supporting cell division is not required for regeneration of auditory hair cells after ototoxic injury in vitro. J Assoc Res Otolaryngol 11:203-222.

Shou J, Zheng JL, Gao WQ (2003) Robust generation of new hair cells in the 
mature mammalian inner ear by adenoviral expression of Hath1. Mol Cell Neurosci 23:169-179.

Slattery EL, Warchol ME (2010) Cisplatin ototoxicity blocks sensory regeneration in the avian inner ear. J Neurosci 30:3473-3481.

Sobkowicz HM, August BK, Slapnick SM (1992) Epithelial repair following mechanical injury of the developing organ of Corti in culture: an electron microscopic and autoradiographic study. Exp Neurol 115:44-49.

Staecker H, Praetorius M, Baker K, Brough DE (2007) Vestibular hair cell regeneration and restoration of balance function induced by math 1 gene transfer. Otol Neurotol 28:223-231.

Stone JS, Cotanche DA (2007) Hair cell regeneration in the avian auditory epithelium. Int J Dev Biol 51:633-647.

Taylor RR, Nevill G, Forge A (2008) Rapid hair cell loss: a mouse model for cochlear lesions. J Assoc Res Otolaryngol 9:44-64.

Timmer J, Johnson J, Niswander L (2001) The use of in ovo electroporation for the rapid analysis of neural-specific murine enhancers. Genesis 29:123-132.

Wang GP, Chatterjee I, Batts SA, Wong HT, Gong TW, Gong SS, Raphael Y (2010) Notch signaling and Atoh1 expression during hair cell regeneration in the mouse utricle. Hear Res 267:61-70.

Warchol ME, Montcouquiol M (2010) Maintained expression of the planar cell polarity molecule Vangl2 and reformation of hair cell orientation in the regenerating inner ear. J Assoc Res Otolaryngol 11:395-406.
Warchol ME, Lambert PR, Goldstein BJ, Forge A, Corwin JT (1993) Regenerative proliferation in inner ear sensory epithelia from adult guinea pigs and humans. Science 259:1619-1622.

Wise AK, Hume CR, Flynn BO, Jeelall YS, Suhr CL, Sgro BE, O’Leary SJ, Shepherd RK, Richardson RT (2010) Effects of localized neurotrophin gene expression on spiral ganglion neuron resprouting in the deafened cochlea. Mol Ther 18:1111-1122.

Woods C, Montcouquiol M, Kelley MW (2004) Math1 regulates development of the sensory epithelium in the mammalian cochlea. Nat Neurosci 7:1310-1318.

Yamamoto N, Tanigaki K, Tsuji M, Yabe D, Ito J, Honjo T (2006) Inhibition of notch/RBP-J signaling induces hair cell formation in neonate mouse cochleas. J Mol Med 84:37-45.

Yamashita H, Oesterle EC (1995) Induction of cell proliferation in mammalian inner-ear sensory epithelia by transforming growth factor alpha and epidermal growth factor. Proc Natl Acad Sci U S A 92:3152-3155.

Zheng JL, Gao W-Q (2000) Overexpression of Math1 induces robust production of extra hair cells in postnatal rat inner ears. Nat Neurosci 3:580-586.

Zheng JL, Keller G, Gao WQ (1999) Immunocytochemical and morphological evidence for intracellular self-repair as an important contributor to mammalian hair cell recovery. J Neurosci 19:2161-2170. 